\title{
Hubungan Tingkat Pendidikan Ibu dan Pendapatan Keluarga dengan Kejadian Stunting pada Balita di Wilayah Kerja Puskesmas Way Urang Kabupaten Lampung Selatan
}

\section{The Relationship between Mother's Education Level and Family Income with Stunting in Toddlers in the Way Urang Community Health Center, South Lampung Regency}

\author{
Sutarto ${ }^{1}$, Tiara Cornela Azqinar ${ }^{2}$, Rani Himayani ${ }^{3}$, Wardoyo $^{4}$ \\ ${ }^{1}$ Bagian Ilmu IKKOM-IKM Fakultas Kedokteran, Universitas Lampung \\ ${ }^{2}$ Fakultas Kedokteran, Universitas Lampung \\ ${ }^{3}$ Bagian Ilmu Kesehatan Mata, Fakultas Kedokteran, Universitas Lampung \\ ${ }^{4}$ Badan Dinklat PPSDM, Provinsi Lampung \\ *korespondensi Penulis: sutarto@fk.unila.ac.id
}

Penyerahan: 18-01-2020, Perbaikan: 23-03-2020, Diterima: 02-05-2020

\begin{abstract}
Stunting is a condition of failure to thrive in children under five (babies under five years old) due to chronic malnutrition so that the child is too short for his age. Factors causing stunting consist of primary factors such as economic factors and mother's education, then intermediate factors such as the number of family members, mother's height, mother's age, and the number of mother's children. This study aims to determine the relation of mother's education level and family income on the incidence of stunting in infants in the Way Urang puskesmas area, South Lampung Regency. Observational analytic research with case-control research design. Sampling uses probability sampling method with a proportional sampling type and a measuring instrument in the form of a questionnaire-data analysis with the chi-square test. The study was conducted on 98 respondents with a low education level of $67.3 \%$ and a low family income level of $55.1 \%$. Statistical test results show that there is a significant relationship between mother's education level and family obedience to the incidence of stunting in infants in the work area of Puskesmas Way Urang South Lampung Regency $(p=0.008$ and $p=0.018$ ). There is a correlation between the mother's education level and family income to the prevalence of stunting among children under five in the work area of Puskesmas Way Urang South Lampung regency.
\end{abstract}

Keywords : Stunting, mother's education level, family income.

\begin{abstract}
ABSTRAK
Stunting adalah kondisi gagal tumbuh pada anak balita (bayi dibawah lima tahun) yang diakibatkan kekurangan gizi kronis sehingga anak terlalu pendek untuk usianya. Faktor penyebab stunting terdiri dari faktor dasar seperti faktor ekonomi dan pendidikan ibu, kemudian faktor intermediet seperti jumlah anggota keluarga, tinggi badan ibu, usia ibu, dan jumlah anak ibu. Penelitian ini bertujuan untuk mengetahui hubungan tingkat pendidikan ibu dan pendapatan keluarga terhadap kejadian stunting pada balita di wilayah puskesmas Way Urang Kabupaten Lampung Selatan. Penelitian analitik observasional dengan desain penelitian case control. Pengambilan sampel menggunakan metode probability sampling dengan jenis proportional sampling dan alat ukur berupa kuesioner. Analisis data dengan uji chi square. Penelitian dilakukan terhadap 98 responden ibu dengan tingkat pendidikan rendah sejumlah $67,3 \%$ dan tingkat pendapatan keluarga rendah sebesar $55,1 \%$. Hasil uji statistik menunjukkan terdapat hubungan yang bermakna antara tingkat pendidikan ibu dan pendaatan keluarga terhadap kejadian stunting pada balita di wilayah kerja Puskesmas Way Urang
\end{abstract}

Jurnal Dunia Kesmas, Vol. 9 No. 2, April 2020, hal. $256-263$

ISSN 2301-6604 (Print), ISSN 2549-3485 (Online)

http://ejurnalmalahayati.ac.id/index.php/duniakesmas/index 
Kabupaten Lampung Selatan $(p=0,008$ dan $p=0,018)$. Terdapat hubungan antara tingkat pendidikan ibu dan pendapatan keluarga terhadap kejadian stunting pada balita di wiayah kerja Puskesmas Way Urang Kabupaten Lampung Selatan.

Kata kunci : Stunting, Pendidikan Ibu, Pendapatan Keluarga.

\section{PENDAHULUAN}

Kejadian stunting pada balita termasuk salah satu permasalahan gizi secara global. Pada tahun 2017 $22,2 \%$ atau sekitar 150,8 juta balita di dunia mengalami stunting. Lebih dari setengah balita stunting di dunia berasal dari Asia (55\%) sedangkan lebih dari sepertiganya (39\%) tinggal di Afrika. Dari 83,6 juta balita stunting di Asia, proporsi terbanyak berasal dari Asia Selatan (58,7\%) dan proporsi paling sedikit di Asia Tengah $(0,9 \%)$. Asia Tenggara pada tahun 2017 memiliki prevalensi kejadian stunting 14,9\%. Kejadian stunting pada balita lebih banyak terjadi di negara berkembang. Indonesia merupakan salah satu negara berkembang yang memiliki kejadian stunting tinggi pada balita (Kementerian Kesehatan Republik Indonesia. 2017).

Sekitar 37\% atau hampir 9 juta anak balita di Indonesia mengalami stunting (Riskesdas. 2013). Indonesia adalah negara dengan prevalensi stunting terbesar kelima di dunia. Pada anak balita dan baduta yang mengalami stunting akan cenderung memiliki kecerdasan yang tidak maksimal, lebih rentan terhadap penyakit, dan dapat berisiko menurunnya tingkat produktivitas di masa depan. Stunting pada akhirnya akan menghambat pertumbuhan ekonomi, meningkatkan kemiskinan, dan memperlebar ketimpangan (Tim Nasional Percepatan Penanggulangan Kemiskinan. 2017). Menurut Riskesdas 2013, prevalensi balita sangat pendek di provinsi Lampung sebesar $27,6 \%$ dan balita pendek sebesar 15\%. Provinsi Lampung masuk dalam kategori wilayah dengan prevalensi balita pendek sangat tinggi. Sedangkan pada tahun 2015 persentase balita sangat pendek di provinsi Lampung sebesar $20,6 \%$, balita pendek sebesar $16,1 \%$ dan normal sebesar $61,3 \%$. Lampung Selatan mempunyai persentase balita sangat pendek sebesar $25,2 \%$ dan balita pendek sebesar $17,8 \%$, persentase ini cukup besar jika dibandingkan dengan persentase kejadian stunting nasional )Dinas Kesehatan Provinsi Lampung. 2015).

Stunting adalah kondisi dimana bayi bawah lima tahun (balita) gagal mengalami pertumbuhan, hal tersebut merupakan dampak dari kurangnya gizi kronis dan menyebabkan anak tersebut terlalu pendek untuk seusianya. Faktor penyebab stunting terdiri dari faktor dasar seperti faktor ekonomi dan pendidikan ibu, kemudian faktor intermediet seperti jumlah anggota keluarga, tinggi badan ibu, usia ibu, dan jumlah anak ibu. Selanjutnya adalah faktor langsung seperti pemberian ASI ekslusif, asupan makan, berat badan lahir rendah (BBLR) (Darteh EKM, Acquah E, Kumi-Kyereme A. 2014).

Perkembangan dan pertumbuhan anak sangat dipengaruhi oleh tingkat pendidikan ibu. Tingkat pendidikan ibu yang rendah merupakan faktor risiko terjadinya keterlambatan perkembangan anak. Ibu dengan tingkat pendidikan yang rendah akan kurang dalam memberikan stimulasi dibandingkan dengan ibu pendidikan 
tinggi. Pola asuh kepada anak, perilaku hidup sehat, ketersediaan dan pola konsumsi rumah tangga dipengaruhi oleh tingkat pendidikan orangtua terutama ibu (Ariani dan Yosopranoto M. 2012). Pendapatan keluarga adalah jumlah penghasilan riil dari seluruh anggota rumah tangga yang digunakan untuk memenuhi kebutuhan bersama maupun perseorangan dalam rumah tangga (Badan Pusat Statistik. 2017). Kemampuan keluarga untuk membeli makanan bergizi dipengaruhi oleh tinggi rendahnya tingkat pendapatan. Pendapatan yang tinggi memungkinkan terpenuhinya kebutuhan makanan seluruh anggota keluarga. Sebaliknya, tingkat pendapatan yang rendah mengakibatkan kurangnya daya beli pangan rumah tangga. Apabila daya beli pangan rendah menyebabkan kurang terpenuhinya kebutuhan gizi balita (Anisa, P. 2012).

Lampung Selatan termasuk dalam 3 besar prioritas intervensi stunting dan beberapa desa di wilayah kerja puskesmas Way Urang sendiri masuk dalam daftar 1000 desa prioritas intervensi stunting, diantaranya Desa Tajimalela dan Desa Taman Agung. ${ }^{9}$ Berdasarkan permasalahan diatas peneliti menilai perlunya dilakukan penelitian terkait hubungan tingkat pendidikan ibu dan pendapatan keluarga terhadap kejadian stunting pada balita.

\section{METODE}

Penelitian ini menggunakan metode analitik observasional dengan pendekatan case control. Penelitian ini dilakukan di wilayah kerja Puskesmas Labuhan Ratu Kota Bandarlampung (Desa Merak Belantung, Tajimalela, dan Taman Agung) pada bulan November 2019. Teknik pengambilan sampel penelitian menggunakan teknik purposive sampling dengan besar sampel sebanyak 98 orang. Populasi pada penelitian ini adalah ibu yang memiliki balita stunting usia 24-59 bulan sebanyak 49 orang dan ibu yang memiliki balita normal usia 2459 bulan sebanyak 49 orang dan berada di wilayah kerja Puskesmas Way Urang Kabupaten Lampung Selatan. Kriteria inklusi pada penelitian ini yaitu responden bersedia menjadi objek penelitian dan hadir saat pengambilan data, ibu yang memiliki balita usia 24-59 bulan, bayi lahir normal dan sehat, responden dapat membaca dan menulis. Kriteria eksklusi penelitian ini adalah balita yang tidak memiliki ibu, balita dengan riwayat infeksi berkepanjangan, balita dengan penyakit jantung bawaan dan balita dengan kelainan kongenital.

Variabel independen (bebas) dalam penelitian ini yaitu tingkat pendidikan ibu dan pendapatan keluarga. Variabel dependen (terikat) dalam penelitian ini yaitu kejadian stunting pada balita di Wilayah Kerja Puskesmas Way Urang Kabupaten Lampung Selatan.

Instrumen yang digunakan dalam penelitian ini adalah kuesioner, Metode pengambilan data menggunakan data primer yaitu wawancara dan kuisioner. Sedangkan data sekunder berupa Laporan tahunan Puskesmas Way Urang Kabupaten Lampung Selatan mengenai daftar nama balita stunting dan normal. Lalu data dianalisis menggunakan analisis univariat dan bivariat (Chi Square).

\section{HASIL}

Pada penelitian ini dapat dilihat data deskriptif mengenai tingkat pendidikan ibu dan pendapatan keluarga di Wilayah Kerja Puskesmas 
Way Urang Kabupaten Lampung

Selatan, yaitu pada tabel 1.

Tabel 1. Distribusi Frekuensi mengenai tingkat pendidikan ibu dan pendapatan keluarga

\begin{tabular}{lcc}
\hline \multicolumn{1}{c}{ Variabel } & Frekuensi & Presentase (\%) \\
\hline Tingkat Pendidikan Ibu & & \\
Rendah (SD, SMP) & 62 & $67,3 \%$ \\
Tinggi (SMA, Diploma, S1) & 32 & $32,7 \%$ \\
Tingkat Pendapatan Keluarga & & \\
Rendah (<Rp.2.168.702) & 54 & $55,1 \%$ \\
Tinggi (>Rp.2.168.702) & 44 & $44,9 \%$ \\
\hline
\end{tabular}

Hasil univariat pada penelitian ini didapatkan data responden dengan pendidikan rendah sebanyak 62 orang $(67,3 \%)$ dan pendidikan tinggi sebanyak 32 orang $(32,7 \%)$. Responden dengan tingkat pendapatan keluarga tinggi sebanyak
$54(55,1 \%)$ dan pendapatan rendah sebanyak $44(44,9 \%)$.

Pada penelitian ini dapat dilihat hasil analisis bivariat mengenai hubungan faktor bebas dan faktor terikat, yaitu pada tabel 2 .

Tabel 2. Hubungan Tingkat Pendidikan Ibu Terhadap Kejadian Stunting

\begin{tabular}{|c|c|c|c|c|c|}
\hline \multirow{3}{*}{$\begin{array}{c}\text { Tingkat Pendidikan } \\
\text { Ibu }\end{array}$} & \multicolumn{4}{|c|}{ Status Gizi } & \multirow{2}{*}{ p value } \\
\hline & \multicolumn{2}{|c|}{ Stunting } & \multicolumn{2}{|c|}{ Normal } & \\
\hline & $\mathbf{n}$ & $\%$ & $\mathbf{n}$ & $\%$ & \\
\hline Rendah & 39 & $79,6 \%$ & 27 & $55,1 \%$ & O18 \\
\hline Tinggi & 10 & $20,4 \%$ & 22 & $44,9 \%$ & 0,018 \\
\hline
\end{tabular}

Hasil penelitian didapatkan bahwa dari 66 responden yang memiliki tingkat pendidikan rendah, sebanyak 39 responden $(79,6 \%)$ memiliki balita stunting dan 27 responden $(55,1 \%)$ memiliki balita normal, sedangkan dari 32 responden yang memiliki tingkat pendidikan tinggi, sebanyak 10 orang $(20,4 \%)$ memiliki balita stunting dan 22 responden
(44,9\%) memiliki balita normal. Hasil uji chi square didapatkan nilai $p$ value $0,018(p<0,05)$, maka dapat disimpulkan bahwa ada hubungan antara tingkat pendidikan ibu terhadap kejadian stunting pada balita di Wilayah Kerja Puskesmas Way Urang Kabupaten Lampung Selatan.

\section{Tabel 3. Hubungan Tingkat Pendapatan Keluarga Terhadap Kejadian Stunting pada Balita}

\begin{tabular}{|c|c|c|c|c|c|}
\hline \multirow{3}{*}{$\begin{array}{c}\text { Tingkat Pendapatan } \\
\text { Keluarga }\end{array}$} & \multicolumn{4}{|c|}{ Status Gizi } & \multirow{3}{*}{ p value } \\
\hline & \multicolumn{2}{|c|}{ Stunting } & \multicolumn{2}{|c|}{ Normal } & \\
\hline & $\mathbf{n}$ & $\%$ & $\mathbf{n}$ & $\%$ & \\
\hline Rendah & 34 & $69,4 \%$ & 20 & $40,8 \%$ & \\
\hline Tinggi & 15 & $30,6 \%$ & 29 & $59,2 \%$ & 0,000 \\
\hline
\end{tabular}


Hasil penelitian didapatkan bahwa dari 54 responden yang memiliki tingkat pendapatan keluarga rendah, sebanyak 34 responden $(69,4 \%)$ memiliki balita stunting dan 20 responden $(40,8 \%)$ memiliki balita normal, sedangkan dari 44 responden yang memiliki tingkat pendapatan keluarga tinggi, sebanyak 15 orang $(30,6 \%)$ memiliki balita stunting dan 29 responden $(59,2 \%)$ memiliki balita normal. Hasil uji chi square didapatkan nilai $p$ value $0,008(p<0,05)$.

\section{PEMBAHASAN}

Hasil penelitian ini terdapat hubungan antara tingkat pendidikan ibu terhadap kejadian stunting pada balita di Wilayah Kerja Puskesmas Way Urang Kabupaten Lampung Selatan. Hal ini sejalan dengan penelitian Setiawan (2018) di Wilayah Kerja Puskesmas Andalas Kecamatan Padang Timur Kota Padang dengan jumlah 74 responden dan didapatkan hasil bahwa terdapat hubungan antara tingkat pendidikan ibu terhadap kejadian stunting pada balita. Penelitian lain yang menunjukkan bahwa adanya hubungan bermakna antar variabel tersebut, diantaranya pada penelitian Kusumawati (2015) di Wilayah Kerja Puskesmas Kedungbanteng, Kabupaten Banyumas dengan jumlah 50 responden dan Ni'mah Rahayu (2015) di Wilayah Kerja Puskesmas Tanah Kali Kedinding dengan jumlah 68 responden.

Penelitian di Nepal oleh Tiwari, et al (2014) menunjukkan hal yang sama bahwa pendidikan ibu berhubungan dengan kejadian stunting balita. Rendahnya pendidikan ibu merupakan penyebab utama dari kejadian stunting pada anak sekolah dan remaja di Nigeria. Ibu yang berpendidikan lebih tinggi lebih memungkinkan untuk membuat keputusan yang akan meningkatkan gizi dan kesehatan anak-anaknya. Tingkat pendidikan ibu juga menentukan kemudahan ibu dalam menyerap dan memahami pengetahuan gizi yang diperoleh. Dari kepentingan gizi keluarga, pendidikan diperlukan agar ibu lebih tanggap terhadap adanya masalah gizi di dalam keluarga dan bisa mengambil tindakan secepatnya (Suhardjo. 2003). Tingkat pendidikan ibu adalah pendidikan formal terakhir yang ditamatkan. Fungsi pendidikan untuk ibu adalah mengembangkan wawasan anak mengenai dirinya dan lingkungan. Tinggi rendahnya tingkat pendidikan ibu tergantung pada lama pendidikan yang ditempuh. Ibu dengan tingkat pendidikan tinggi akan lebih mudah menerima informasi kesehatan khususnya tentang cara mendidik balita sehari hari. Faktor yang dapat mempengaruhi perkembangan balita yaitu cara merawat dan mendidik. Ibu dengan pendidikan rendah akan sulit menerima informasi, sehingga anak yang hidup dalam keluarga dengan tingkat pendidikan dasar cenderung mengalami pertumbuhan yang lambat karena pola pengasuhan yang diberikan pada anak (Departemen Kesehatan RI. 2008).

Tingkat pendidikan ibu berpengaruh terhadap konsumsi makanan anak yang disebabkan oleh pola pikir dan pengalaman. Tingkat pendidikan ibu yang tinggi akan lebih memilih makanan yang kualitasnya lebih baik dari pada yang tingkat pendidikannya rendah. Ibu dengan pendidikan tinggi akan lebih memilih makanan yang memiliki kandungan gizi yang tinggi sesuai dengan pangan yang tersedia dan kebiasaan makan sejak kecil, sehingga kebutuhan gizi terpenuhi. Dilihat dari kualitas makanan yang dikonsumsinya, ibu berpendidikan tinggi akan lebih kritis dalam pemilihan makan, keburukan, dan 
risiko dalam konsumsi makanan. ${ }^{12}$ Tingkat pendidikan ibu yang lebih tinggi memiliki hubungan terhadap pengasuhan yang baik pada anak, seperti: penggunaan garam beryodium, pemberian kapsul vitamin $A$, imunisasi yang lengkap dan sanitasi yang baik. ${ }^{13}$ Penelitian Ramli et al di Maluku (2009) menemukan bahwa pendidikan ibu berhubungan signifikan dengan kejadian stunting pada balita.

Terdapat hubungan antara tingkat pendapatan keluarga dengan kejadian stunting pada balita di Wilayah Kerja Puskesmas Way Urang Kabupaten Lampung Selatan pada penelitian ini. Hal ini sejalan dengan penelitian Setiawan (2018) di Wilayah Kerja Puskesmas Andalas Kecamatan Padang Timur Kota Padang dengan jumlah 74 responden dan didapatkan hasil bahwa terdapat hubungan antara tingkat pendapatan keluarga terhadap kejadian stunting pada balita.

Hasil penelitian lain yang menunjukkan bahwa adanya hubungan bermakna antar variabel tersebut, diantaranya pada penelitian Kusumawati (2015) di Wilayah Kerja Puskesmas Kedungbanteng, Kabupaten Banyumas dengan jumlah 50 responden, Ni'mah Rahayu (2015) di Wilayah Kerja Puskesmask Tanah Kali Kedinding dengan jumlah 68 responden, dan Husein Al Anshori (2013) tentang Faktor Risiko Kejadian Stunting Pada Balita di Kecamatan Semarang Timur. Pendapatan merupakan salah satu indikator yang menentukan status ekonomi. Hasil penelitian di Nepal menunjukkan bahwa indeks kekayaan rumah tangga merupakan faktor risiko stunting (Tiwari, R., Ausman, L. M., Argho, K. E. 2014). Skor indeks kesejahteraan rumah tangga yang lebih tinggi berhubungan signifikan dengan peningkatan proteksi kejadian stunting (Gewa, C.A and Yandel, N. 2012).

Pendapatan keluarga adalah jumlah penghasilan riil dari seluruh anggota rumah tangga yang digunakan untuk memenuhi kebutuhan bersama maupun perseorangan dalam rumah tangga. Pendapatan keluarga termasuk balas jasa atau imbalan yang diperoleh atas fakor produksi yang dilakukan. ${ }^{\mathbf{1 7}}$ Peneliti mengklasifikasikan pendapatan rendah tinggi berdasarkan UMR Lampung Selatan. Upah Minimum Provinsi (UMP) tahun 2018 telah ditetapkan Gubernur Lampung adalah sebesar Rp 2.074.673 sedangkan Upah Minimum Kabupaten Lampung Selatan telah ditetapkan sebesar Rp2. 168. 702 (Anisa, P. 2012).

Kemampuan keluarga untuk membeli makanan bergizi dipengaruhi oleh tinggi rendahnya tingkat pendapatan. Pendapatan yang tinggi memungkinkan terpenuhinya kebutuhan makanan seluruh anggota keluarga. Sebaliknya, tingkat pendapatan yang rendah mengakibatkan kurangnya daya beli pangan rumah tangga. Apabila daya beli pangan rendah menyebabkan kurang terpenuhinya kebutuhan gizi balita (Sumarwan, Ujang. 2002). Tingkat pendapatan yang tinggi memberi peluang lebih tinggi bagi keluarga dalam memilih bahan pangan baik jumlah maupun jenisnya. Pendapatan yang diukur biasanya bukan hanya pendapatan yang diterima oleh seorang individu, tetapi diukur semua pendapatan yang diterima oleh semua anggota keluarga dimana konsumen berada. Jumlah pendapatan keluarga dapat mempengaruhi ketersediaan pangan disebuah keluarga, karena pendapatan akan memenuhi kebutuhan pangan sesuai dengan daya belinya. Daya beli sebuah rumah tangga bukan hanya

Jurnal Dunia Kesmas, Vol. 9 No. 2, April 2020, hal. $256-263$

ISSN 2301-6604 (Print), ISSN 2549-3485 (Online)

http://ejurnalmalahayati.ac.id/index.php/duniakesmas/index 
ditentukan oleh pendapatan dari satu orang, tetapi dari seluruh anggota rumah tangga yang bekerja (Sumarwan, Ujang. 2002).

\section{KESIMPULAN}

Berdasarkan uraian sebelumnya, maka kesimpulan dari penelitian ini adalah terdapat hubungan antara tingkat pendidikan ibu dan pendapatan keluarga terhadap kejadian stunting pada balita di Wilayah Kerja Puskesmas Way Urang Kabupaten Lampung Selatan.

\section{DAFTAR PUSTAKA}

Kementerian Kesehatan Republik Indonesia. (2017). Buku Saku Pemantauan Status Gizi. Jakarta : Direktorat Gizi Masyarakat dan Direktorat Jendral Kesehatan Masyarakat.

Riskesdas. (2013). Laporan Nasional Riset Kesehatan Dasar (Riskesdas Tahun 2013). Jakarta : Badan Penelitian dan Pengembangan Kesehatan Departemen Kesehatan RI.

Tim Nasional Percepatan Penanggulangan Kemiskinan. (2017). 100 Kabupaten/kota prioritas untuk intervensi anak kerdil (stunting). Vol 2. Jakarta: Sekertariat Wakil Presiden Republik Indonesia.

Dinas Kesehatan Provinsi Lampung. (2015). Profil Kesehatan Provinsi Lampung Tahun 2015. Dinas Kesehatan Provinsi Lampung, Bandar Lampung.

Darteh EKM, Acquah E, KumiKyereme A. (2014). Correlates of stunting among children in ghana. BMC Public Health. 14(1):2-7.

Ariani dan Yosopranoto M. (2012). Usia anak dan pendidikan ibu sebagai faktor risiko gangguan perkembangan anak. Jurnal Kedokteran Brawijaya.

$$
\text { 27(2): 118-121. }
$$

Badan Pusat Statistik. (2017). Pengeluaran Untuk Konsumsi Penduduk Indonesia Per Provinsi, Maret 2017. BPS. Jakarta.

Anisa, P. (2012). Faktor-faktor yang berhubungan dengan kejadian stunting pada balita usia 25-60 bulan di Kelurahan Kalibiru Depok tahun 2012 [Skripsi]. Jakarta: Universitas Indonesia.

Kementerian Kesehatan Republik Indonesia. (2017). Buku saku pemantauan status gizi. Jakarta:Direktorat Gizi Masyarakat dan Direktorat Jendral Kesehatan Masyarakat.

Suhardjo. (2003). Berbagai Cara Pendidikan Gizi. Jakarta: Bumi Aksara.

Departemen Kesehatan RI. (2008). Sistem Kesehatan Nasional. Jakarta: Departemen Kesehatan RI

Nasikhah, Roudhotun. (2012). Faktor Risiko Kejadian Stunting pada Balita Usia 24-36 bulan di kecamatan Semarang Timur. Journal Of Nutriton College. 1(1) : 715 - 730.

Supriyanti, NT. (2014). Hubungan antara pola konsumsi dan kejadian infeksi dengan status gizi balita usia 12-59 bulan di desa Baban, Kecamatan Gapura Sumenep. Skripsi. Universitas Airlangga

Tiwari, R., Ausman, L. M., Argho, K. E. (2014). Determinants of stunting and severe stunting among under-fives:evidence from 2011 Nepal Demographic and Healthy Survey. BMC Pediatrics, 14, 239.

Gewa, C.A and Yandel, N. (2012). Undernutrition among kenyan children: contribution of child, maternal, and household factors. Public Health Nutrition. 15:2938.

Badan Pusat Statistik. (2017). 
Pengeluaran Untuk Konsumsi Penduduk Indonesia Per Provinsi, Maret 2017. BPS. Jakarta.

Bank Indonesia. (2018). Kajian ekonomi dan keuangan regional provinsi lampung 2018. Kepala Perwakilan Bank Indonesia Provinsi Lampung. 151:10-17.

Anisa, P. (2012). Faktor-faktor yang berhubungan dengan kejadian stunting pada balita usia 25-60 bulan di Kelurahan Kalibiru Depok tahun 2012 [Skripsi]. Jakarta: Universitas Indonesia.

Sumarwan, Ujang. (2002). Perilaku konsumen. Jakarta: Ghalia Indonesia. 